\title{
TCOM \\ The power of storytelling and video: a visual rhetoric for science communication
}

\section{Wiebke Finkler and Bienvenido León}

\begin{abstract}
This research develops a conceptual framework for telling visual stories about science using short-format videos, termed SciCommercial videos, that draw upon marketing communication. The framework is illustrated by an exemplar, the Good Whale Watching video, which is explained using a visual rhetoric keyframe analysis. Finally, the effectiveness of the video is evaluated as a science communication tool using an empirical online survey with 1698 respondents. The results highlight the benefits of using video for storytelling about science by using our framework formula, modified from marketing practices, to produce videos that are Simple, Unexpected, Concrete, Credible, Emotional, Science Storytelling (SUCCESS).
\end{abstract}

Keywords

DOI

Introduction
Science and media; Science communication: theory and models; Visual communication

https://doi.org/10.22323/2.18050202

Submitted: 28th February 2019

Accepted: 19th August 2019

Published: 14th October 2019

The power of storytelling and video

We live in the screen age: screens are used for informing, entertaining and communicating. Developments in technology have led to an abundance of television stations, internet and digital resources for the public to access information about science [Bucchi and Trench, 2014]. This digital revolution provides opportunities to connect science with audiences [Wilkinson and Weitkamp, 2016]. Of the new digital technologies, video consumption is the most rapidly growing area of mass communication [Vorbau, Mitchell and O'Hara, 2007], and online video now constitutes over $75 \%$ of all global Internet traffic [Cisco, 2018]. New mobile technologies are creating dramatic shifts in the ways that video-based content can be produced, consumed, and delivered [Vorbau, Mitchell and O'Hara, 2007]. Social media are facilitating a democratization of media production and a power shift towards consumers who can produce video content and publish via social media communication channels such as YouTube 
[DesAutels, 2011; Kietzmann et al., 2011; Peters et al., 2013]. This democratization of filmmaking arises from the availability of gear and software for filmmaking that is user-friendly and affordable, combined with the advent of free and easy means of distribution.

The seismic shift to video consumption provides a significant opportunity to use film for the purposes of science communication in very cost-effective and far reaching ways [Roe, 2014]. However, how to leverage this brave new world of screens with skill and creativity is an important challenge that science communicators need to solve. The screen can potentially become a market place for science communication, but like any marketplace it is only as good as the content that flows through it: science products, ideas, information, developments and discoveries, and how they are packaged for science audiences will be crucial to its success [Finkler, 2018]. New narrative forms become possible, which potentially can become tools of great efficacy for communicating science [León and Bourk, 2018].

Science storytelling in films has been used to educate and influence a wide range of audiences around the world [Barbas, Paraskevopoulos and Stamou, 2009; Pearson, Dorrian and Litchfield, 2011; D. Whiteman, 2009]. As humans, we are "essentially an animal that tells stories" [McIntyre, 1984, p. 266] whereby telling stories was the traditional way that societies passed on ideas and information. Films have an advantage for storytelling as they are able to "visually transport people to places and situations they might otherwise never experience" [M. E. Norman, 2000, p. 28]. This provides a crucial advantage to using video for science communication: when an audience is distanced from an issue, they are unlikely to take-action, but a video can potentially take them there and make them care [Wright, 2010].

Narratives have the power to influence the persuasiveness of a message and influence an individual's beliefs, attitudes and behaviour, a characteristic termed narrative persuasion [de Graaf et al., 2012; Green and Brock, 2000; Green, 2004; Hoeken and Sinkeldam, 2014]. This experience of becoming absorbed or lost in a story is referred to as "transportation" [Beamish, 2016]. There are three ways in which transportation influences an audience: by creating connections and identification with characters, reducing counter arguing of assertions made in the story, and increasing realism and credibility by providing concrete forms to abstract ideas. Characters are an essential part of narrative and storytelling in film as the audience can identify with a character and feel empathy towards his or her goals [de Graaf et al., 2012; Green and Brock, 2000]. This identification results in "relating to characters" [Green, 2006, p. S166], and an increased likelihood of change in their own attitudes, beliefs and behaviour [de Graaf et al., 2012].

The video format has become a popular and effective communication channel for broad audiences because "film is a language that everyone learns to 'read' from a very early age" [Olson, 2009, p. 9]. Narrative that is coupled with emotive imagery aids transportation and is likely to increase the persuasiveness of the message [Beamish, 2016; Roberts, 2005]. This is important because as Burns, O'Connor and Stocklmayer [2003, p. 191] proclaim in their definition of science communication: "for science communication to be effective - in fact, to allow any valid assessment of its effectiveness - it must always have predetermined and appropriate aims." Thus, the persuasiveness of a narrative will be critical to its success as a science communication tool and this is where storytelling via video can have a distinct advantage. 
The making and uploading of videos is now a common everyday practice: on YouTube alone, 300 hours of video are uploaded every minute of the day, and 4.95 billion videos are viewed every day by its more than 1.3 billion users [Statistic Brain Research Institute, 2016]. As science communicators, we need to be providing content in the format that it is being consumed in. For the most part, however, scientists and science communicators lack crucial know-how on how to design effective science communication videos [Olson, 2009]. While traditionally they have focused on content and substance [Peters, 2014], they must come to realize that "style matters when it comes to communication" [Olson, 2009, p. 11].

Another change that has taken place in the shift from traditional broadcast media such as television to online on-demand videos is the shortening of the duration of videos [León and Bourk, 2018]. This is particularly true of younger consumers, where those less than 30 already get the majority of their entertainment and information from online on-demand sources [Davis and León, 2018]. Traditional science documentaries have long adhered to the conventional expository format for their narrations [León, 2007; Davis and León, 2018]. However, for short-form videos, marketing communication can potentially assist with the communication of science [Roberts, 2005; Shimp and Andrews, 2013]. Television commercials and public service announcements typically tell a story in less than one minute, and represent a highly effective, tested and established form of visual storytelling [Olson, 2009; Roberts, 2005]. Marketing communication has been successfully used for many social issues, including drink driving, obesity and anti-smoking initiatives, by increasing public awareness and promoting behaviour change [Hall, 2014; Lee and Kotler, 2011]. Increasingly authors are recognizing the potential of marketing and public relation practices to aide science communication [Bucchi and Trench, 2014; Nisbet and Scheufele, 2009; G. Whiteman, 1999].

\section{Marketing for science communication}

In 1985, marketing was defined by the American Marketing Association as "the process of planning and executing the conception, pricing, promotion, and distribution of ideas, goods, and services to create exchanges that satisfy individual and organizational goals" [Gundlach, 2007, p. 243]. Similar to science communication, marketing communication developed over time to include participatory aspects and focus on a social and value exchange process with benefits for the wider society. Consequently, in 2007 marketing was defined as "the activity, set of institutions, and processes for creating, communicating, delivering, and exchanging offerings that have value for customers, clients, partners, and society at large" [Gundlach and Wilkie, 2009, p. 260]. Still, widespread confusion and contempt for marketing have persisted, and many scientists are uneasy about relying on the "dark arts" [Smith, Veréssimo and MacMillan, 2010, p. 215] that are also used to sell cigarettes and soap [Kaczynski, 2008; Schwartz, 2006].

Marketing communication has several important benefits to offer science communication, as its largely quantitative nature and emphasis on metrics and evaluation can make messages more appealing and can be used to positively influence public behaviour [Smith, Veréssimo and MacMillan, 2010; Wright, 
Veríssimo et al., 2015]. While some critics from the science communication field may consider it unethical to take advantage of strategic communication tools [Smith, Veréssimo and MacMillan, 2010], others argue that the current environmental crisis and widening knowledge gaps in society about science and technology suggest that it is unethical not to use all communication tools available to reach audiences [Nisbet and Scheufele, 2009; Smith, Veréssimo and MacMillan, 2010; G. Whiteman, 1999].

Marketing communication directs its effort towards influencing the fundamentals of consumer choice behaviour (beliefs, attitudes, emotional reactions and choices), to influence and change human behaviour [Shimp and Andrews, 2013]. Marketing at its core is based on exchange theory, which has its foundation in psychology and economics, and assumes that people are need-directed beings with a built-in inclination to improve ones' existence [Houston and Gassenheimer, 1987]. To increase consumers' readiness to change their behaviour, the marketer must provide something beneficial in exchange. In this sense, exchange involves the transfer of tangible or intangible items between two or more social actors [Bagozzi, 1974].

According to the Theory of Planned Behaviour by Fishbein and Ajzen [1977], an individual's attitude towards a behaviour, the influence of subjective norms, and perceived behavioural control determine whether the individual will adopt the behaviour or not [Ajzen, 2002]. In theory, the three components of attitude, subjective norms and perceived behavioural control result in behavioural intentions being formed [Ajzen, 1991]. If individuals have a reasonable amount of actual control it is expected that they will act on their intentions and perform the behaviour. "Intention is thus assumed to be the immediate antecedent of behaviour" [Ajzen, 2002, p. 665], and measuring "intentions" can be a valid way to evaluate the effectiveness of communication.

While many science communication activities may not necessarily have behaviour change in mind, arguably all communication, including science communication, seeks to influence behaviour in some way [Wilkinson and Weitkamp, 2016]. Marketing communication advances audiences through a series of psychological stages, or hierarchy of effects, with the AIDA Model of hierarchical effects (Attention, Interest, Desire, and Action) being the most popular and widely used way to measure the effect of communication strategies [Hassan, Nadzim and Shiratuddin, 2015]. According to this model, audiences respond to messages in a systematic way: (i) cognitively/thinking, (ii) affectively/feeling, and (iii) conatively/doing [Wijaya, 2015]. A marketing-based, outcome-type approach to science communication can advance audiences through a similar series of psychological stages. This would lead to a change in an audiences' attention and awareness, to an interest and desire for action.

\section{An example for testing: the science about whale watching}

Whale watching is a worldwide multibillion-dollar industry, attracting at least 13 million people every year [O'Connor et al., 2009]. Since the Save the Whale movement of the 1970s, whale watching around the world has experienced explosive growth, and is universally viewed and marketed as the green alternative to whaling [Neves, 2010]. However, scientists have demonstrated that whale 
watching can have negative consequences for the behaviour and breeding success of whales, with the most serious impacts caused by the close proximity of whale watching boats to the whales [Higham, Bejder and Williams, 2014], which causes disturbance and underwater noise pollution [Jensen et al., 2009; Orams, 2000; Tyack, 2008; Wright, Deak and Parsons, 2011]. This can result in reduced reproduction rates and, ultimately, affect a whale population's fitness [Bejder et al., 2006]. Ironically, it is proximity to whales that is most promoted by the marketing of whale watching, developing in consumers an expectation that a good whale watching experience is a close one [Finkler, 2014].

The whale watching industry is complex, involves multiple stakeholders and multilevel governance [Higham, Bejder and Williams, 2014]. The science about whale watching is unambiguous: its results must be communicated in ways that alter people's currents perceptions of whale watching and promote sustainable management practices, or the viability of many whale populations will be negatively impacted. Short-form videos and marketing communication seem ideally suited to the task at hand [Truong and Hall, 2013; Veríssimo, 2013]. Here, we put forward a marketing-based science communication video format, the SciCommercial video, that draws on marketing communication to package science content. Further, we test the effectiveness of this marketing-based approach to science communication by way of an exemplar that focuses on sustainable whale watching.

The objectives and aims of marketing-based science communication about whale watching could be varied, ranging from influencing public awareness about responsible whale watching, attitudes and behavioural intentions in regard to boat practices or whale watcher's preference for responsible operators, to specific behaviour change related outcomes such as using boat engines which reduce underwater noise emission, switching of engines when with whales, or engaging in responsible online marketing of whale watching to create realistic visitor expectations. Here, we concentrate on how to communicate some of the science of whale watching to both consumers and operators so that it alters their attitudes and behavioural intentions. We produce a Good Whale Watching video using our marketing communication derived format as the basis for our storytelling, and then we test its effectiveness. Our objectives are to demonstrate: (i) the main characteristics that a video must have to communicate science effectively, and (ii) how viewers perceive such characteristics.

We used a mixed-method research approach that involved: (i) the development of a conceptual literature-based storytelling framework for videos about science, called a SciCommercial, that draws upon marketing communication, (ii) the production of a SciCommercial science communication video on sustainable whale watching as an exemplar, and (iii) the evaluation of that video. The outcome of all this is intended to contribute towards the development of a visual rhetoric for science communication.

\section{Literature review}

We undertook a literature review of key marketing communication literature to extract approaches relevant to the communication and storytelling about science in videos. 
The research involved the production and evaluation of a two-minute science communication video, called the Good Whale Watching SciCommercial https:/ / youtu.be/AoF416F7vzE. It merged scientific literature on whale watching and marketing communication, with input from two research focus groups $(\mathrm{N}=19)$ with whale watching experts, to identify science content for the video [Finkler, 2018]. The video employs a participatory, multi-stakeholder approach to the communication of relevant science (that is, whale watching operators, scientists and participants all feature in the video and contribute to the communication of content). The video was produced with advisory input from marketing professionals as well as scientists, and evaluated using online Qualtrics survey software.

\section{Survey}

The assessment and evaluation of the video was conducted using self-completion questionnaire surveys administered online [Bryman, 2008]. The survey design was based upon a review of existing literature [Foddy and Crundall, 1993; G. Norman, 2010; Robson, 2011; Robson and McCartan, 2016; Thomas, 2014], as well as advisory input from social science researchers. Development of the survey included pre-testing $(\mathrm{n}=38)$ and pilot-testing $(\mathrm{n}=50)$.

The survey intended to assess the effectiveness of our proposed SciCommercial storytelling format as a science communication tool, and its capacity to influence behavioural intentions such as sharing the video and visiting the related website. The survey contained a combination of mostly closed questions with some open-ended questions. Five-point Likert scaling was used due to its power and simplicity of format [Robson, 2011]. Appropriate filter categories allowed respondents to opt out if they had no opinion or their position was neutral. The order of the sub-questions was randomized through the online survey software.

Respondents' were asked to rate their likelihood to engage in certain behaviours including 'to share this video with friends on social media, find out more about Good Whale Watching practices, tell someone else about this video, choose a tour operator who promotes responsible whale watching practices, and visit the website promoted in the video'. In addition, respondents were asked to rate the video in terms of specific adjectives including 'concerning, depressing, empowering, believable, real, memorable, emotional, telling a story, scientific, solution-focused, motivational, authoritative, informative, and engaging'. Open-ended questions aimed to assess how members of the public interpreted the video, including 'what they liked most about the video'.

The video was published online and hosted on the platform Vimeo, as well as linked to a website designed solely for the purpose of this research: http:/ / www.goodwhalewatching.com/. People were invited to participate in the research using social media (Facebook, Twitter). Initially 250 Facebook friends were invited to participate in the research and asked to share the survey. In addition, the survey was promoted on relevant tourism, conservation and whale-related Facebook pages. From these initial Facebook publications, the survey was shared and distributed widely in various whale, conservation and science communication 
forums. Surveys were coded and the collected data were analysed using SPSS (the Statistical Package for Social Science Research) software. A total (N) of 1698 surveys were collected online. However, the number of total completions for individual questions varied. For the analysis of questions, descriptive analyses and cross-tabulation were used.

At the heart of successful marketing communication strategies lie sticky successful ideas [Heath and Heath, 2007] that can be characterised as simple, unexpected, concrete, credible, emotional stories, or SUCCES for short [Shimp and Andrews, 2013]. Based on an analysis of hundreds of contagious messages that got shared virally, Berger and Milkman [2012] identified six essential ingredients of contagious ideas or content: social currency (how it makes people look to talk about products), triggers (stimuli that prompt people to think about related things), emotion (when we care, we share), public (need to make products and ideas more public), practical value (useful content), and stories (narrative used to translate the idea; stories carry moral and lessons).

We appropriated these ingredients from marketing communication, in a somewhat modified form (SUCCESS) to use for science storytelling in short-format videos, which we term a SciCommercial format (Table 1). Sticky (memorable) successful science ideas portrayed using this format should be understandable, memorable, and effective in changing thought or behaviour [Heath and Heath, 2007] by providing practical content, public visibility, social currency and emotion, leading to social diffusion. If audiences care about an issue they are more likely to share and discuss it within their networks [McKenzie-Mohr, 2011], and in the online social-media driven environment, sticky science ideas are needed to make the audience pay attention, understand and remember, agree/believe, care and be able to act on it (Table 1).

Table 1. SciCommercial principles of simple sticky science ideas. Source: adapted by us from Heath and Heath [2007] and Shimp and Andrews [2013].

\begin{tabular}{|ll|}
\hline A sticky science idea must make the audience & A sticky idea must be \\
\hline Unconfused & SIMPLE \\
Pay attention & UNEXPECTED \\
Understand and remember it & CONCRETE \\
Agree/believe & CREDIBLE \\
Care & EMOTIONAL \\
Connect with science & SCIENCE \\
Be able to act on it & STORYTELLING \\
\hline
\end{tabular}

The elements of SUCCESS are adopted from Heath and Heath [2007] and Shimp and Andrews [2013] and defined for our science storytelling purposes as follows:

\section{Simplification}

Effective pieces of communication keep things simple and clear [Lee and Kotler, 2011]. Simplification is one of the main principles of audio-visual science 
communication [León, 2007]. Simplicity is defined not in terms of dumbing down the science but instead refers to prioritization and finding the core of the idea. In fact, research has shown that non-specialists do not need to understand most of the scientific details to be able to discuss the social and ethical implications [Office of Science and Technology \& Wellcome Trust, 2001]. The core idea should be the lead for a story, or the hook, that draws people into the story. Succinct, compact ideas help people learn and remember a core message [Heath and Heath, 2007]. In the case of the whale watching example, the core idea is that whale watching can harm whales and it is, therefore, essential to respect their space so that the experience will be sustainable for both whales and watchers.

\section{Unexpectedness}

Effective communication generates interest and curiosity if it deviates from the audiences' expectations and has an element of novelty [Shimp and Andrews, 2013]. Science content, at its heart, is based on uncovering and revealing the unknown. It is founded on a process of discovery and revelation [Kelsey, 2012; Swaisgood and Sheppard, 2010], all of which are key elements of effective science storytelling. Good communicators, therefore, first need to violate people's expectations, reveal gaps in their knowledge (creating an emotional need) and then fill those gaps [Heath and Heath, 2007]. Lee and Kotler [2011] note that sometimes the very act of asking a question can be a force for driving a message of positive change. For example, it can be very effective to surprise audiences by starting with a question - such as, What is good whale watching? - rather than telling people how to act.

\section{Concreteness}

Effective communication concretizes messages to facilitate audience learning, as it is easier for people to remember and retrieve concrete versus abstract information [Shimp and Andrews, 2013]. Here, abstract language refers to intangible qualities, ideas and concepts (things we know through our intellect) while concrete language refers to tangible qualities or characteristics (things we experience through our senses). Scientists often struggle with translating their abstract concepts into concrete descriptions that an audience can more readily understand, making this an important job for science communicators to do in their visual storytelling. In our whale watching exemplar, the audience is presented with concrete words such as "whale-boat collision." Such words evoke distinct images in the audience's mind. Abstract phrases like sustainable whale watching, by comparison, are unlikely to evoke distinct and predictable images. These word-generated pictures and visuals are better remembered than words alone because pictures are especially able to elicit mental images and be recalled [Shimp and Andrews, 2013].

\section{Credibility}

Credibility is about how to make people believe the scientific ideas that are being communicated. Effective communication has to be believable, have a sense of authority, and provide information or support for why it should be accepted as a fact [Shimp and Andrews, 2013]. Scientists, in general, are regarded as trustworthy and valued experts due to their reputation for providing systematic, empirical 
research [Peters, 2014; Shapin, 2008]. The perception that a source is fair, unbiased and truthful contributes to the trustworthiness of information [Rieh, 2010]. The whale watching example includes a well-known whale researcher who is widely viewed as a trustworthy figure.

Credibility is also influenced by likability, which in turn can be influenced by celebrity status and fame [Binet and Field, 2009; Shimp and Andrews, 2013]. Through watching a science video, the audience may identify with a character, care about them, feel empathy within their goals, and put oneself in the characters' place [de Graaf et al., 2012; Green, 2006; Green and Brock, 2000]. Character identification through sympathetic characters is, therefore, crucial to increase narrative persuasion and should be used in video-based science communication initiatives. Hence, the scientist, operator, whale watchers as well as mother whale and whale calf used in our video were all chosen for their likeability on screen and ability to generate empathy with viewers.

\section{Emotions}

Credibility further relates to authenticity where the trustworthiness of a message can be enhanced by showing authentic human reactions, that is, capturing people in the act of being themselves [Voltz and Grobe, 2012]. For our whale watching example, we show authentic emotional responses of people watching whales. This approach has potential for the purposes of science communication as showing the authenticity of something will equate to its honesty, which is a crucial currency when it comes to the viral diffusion of content [Voltz and Grobe, 2012]. Marketing communication that uses emotional appeal is much more effective than rationally based models that rely on providing information alone [Binet and Field, 2009], which argues strongly for a more widespread adoption of emotion as a tool for science communication.

An important element of storytelling for short-form video is the adoption of positive messages for science communication. Positive emotions such as hope are beneficial in the long-term and broaden an individuals' thought-action repertoire [Garland et al., 2010; Weinreich, 2010]. Negative emotions, such as sadness, are unlikely to increase the virality of videos [Berger and Milkman, 2012]. For the most effective form of science storytelling in videos, then, it is best to create content that evokes emotions such as hope and awe but to avoid negative emotions such as sadness or fear. For our whale watching example, while there is a need to communicate risk and threats, it is crucial to highlight solutions and messages of hope or else risk paralysing the audience [Joffe, 2008].

\section{Science}

Science is at its core a discipline of discovery [Hanson, 1965]. Science storytelling, therefore, needs to identify hooks about science that link in with people's curiosities and everyday lives [Saunders, Brook and Myers, 2006]. This can be done by communicating with metaphors and stories, and communicating through affective imagery that evoke associations and relevance to audience's lives [Kearney, 1994; Leiserowitz, Kates and Parris, 2005]. In our whale watching exemplar, scientific studies have highlighted that whales exhibit behavioural changes in response to 
whale-watching boat traffic, and that whale watching can impact essential behaviours such as breeding, feeding or resting [Bejder et al., 2006; Parsons, 2012]. This can reduce fitness of whale populations [Wright, Soto et al., 2007]. We communicate this science using the allusion of boat collisions and a soundscape that underscores the "threats" posed by people compared to the "tranquillity" of the whales when they are undisturbed. We do this in a positive way that brings together the various stakeholder perspectives (scientists, whale watching operators, tourists), while emphasising their likability and compassion for the whales [Olson, 2009].

\section{Storytelling}

Humans are strongly pre-disposed for narratives and certain emotional structures that are triggered when we encounter stories, images and human interaction [Bondebjerg, 2014]. Furthermore, storytelling is a fundamental basis of many examples of audio-visual science communication [León, 2007]. Classic storytelling typically involves a three-act structure with a beginning, a middle, and an end [McKee, 2016]. Most stories follow the simple idea of what happens next.

Olson [2009] provides an alternative approach for thinking about story structure for science stories called ABT (and, but, therefore). In our whale watching example, it is structured according to the ABT model of storytelling: whale watching has grown into a multibillion-dollar global industry and millions of people go whale watching every year, largely driven by a human desire to experience whales in close proximity but scientific research shows that approaching whales too close with boats can have significant negative impacts on the whales' breeding and behaviour therefore to save whales for future generations, we need to choose whale watching operators who promote responsible practices rather than close-encounters.

The Good Whale Watching video applied the principles of our short-form video, SciCommercial storytelling format in ways that are summarized in Table 2.

A keyframe analysis describes the filmmaking techniques and communication purpose of each shot used in the video. This type of analysis is useful for understanding the video production process [Zettl, 2013]. Excerpts from a keyframe analysis undertaken of the Good Whale Watching video are outlined in Table 3 to illustrate how specific ingredients of the filmmaking process have been used to comply with the SUCCESS format for science storytelling in short videos.

Survey

Most of the survey respondents $(\mathrm{N}=1698)$ resided in North America $(34.4 \%)$, Australasia (33.1) and Europe (27.2), followed by South America (3\%), Asia (1.9\%) and Africa (0.5\%). The top six countries represented were the United States $(26.8 \%)$, New Zealand (23.7\%), Australia (7.8\%), Canada (7.4\%), the United Kingdom $(7.1 \%)$ and Germany (7\%). Most of the participants were female (71.8\%) compared to males $(28.2 \%)$. The majority of respondents were spread equally between the ages of $26-55(26-35=21.9 \%, 36-45=21 \%, 46-55=22 \%)$. Overall, participants were highly educated with over $80 \%$ holding a tertiary qualification (i.e., bachelor or postgraduate degrees). 
Table 2. SciCommercial format applied to the Good Whale Watching SciCommercial video.

\begin{tabular}{|c|c|}
\hline $\begin{array}{l}\text { SciCommercial } \\
\text { Element }\end{array}$ & Whale Watching Context \\
\hline Simple & $\begin{array}{l}\text { Core idea: whale watching can harm whales; solution: good whale } \\
\text { watching; respect their space and adhere to guidelines and the exper- } \\
\text { ience will be good for both whales and watchers }\end{array}$ \\
\hline Unexpected & $\begin{array}{l}\text { Revealing potential impacts and scale of industry; showing whale } \\
\text { watching from whales' perspective }\end{array}$ \\
\hline Concrete & $\begin{array}{l}\text { Tangible, substantive words and demonstrations; underwater noise } \\
\text { pollution demonstrated with sound and video from whale perspect- } \\
\text { ive and related to proximity and collision scene }\end{array}$ \\
\hline Credible & $\begin{array}{l}\text { Various stakeholders with same message; science and operator cred- } \\
\text { ibility; authentic human reactions and emotions; long unedited shots } \\
\text { of underwater-above water showing the whale-human worlds in- } \\
\text { creases credibility of real events }\end{array}$ \\
\hline Emotional & $\begin{array}{l}\text { Clips of mother-calf bond; authentic positive emotions of whale } \\
\text { watchers; positive message from key stakeholders focusing on } \\
\text { mutual element of respect for whales and good whale watching; } \\
\text { solution-focused practical advice }\end{array}$ \\
\hline Science & $\begin{array}{l}\text { Uncovering relevant and hard-to-see science in regard to whale } \\
\text { watching proximity, underwater noise and disturbance of essential } \\
\text { whale behaviours combined with fact-checking }\end{array}$ \\
\hline Storytelling & $\begin{array}{l}\text { Effective storytelling while being the voice of science; beginning in- } \\
\text { tro of underwater world and mother-calf bond, middle with whale } \\
\text { watching impacts and jeopardy of collision scene; ending promoting } \\
\text { respectful whale watching focused on animal welfare 'Good for the } \\
\text { whales means good for the watchers' }\end{array}$ \\
\hline
\end{tabular}

After watching the video, respondents reported they were most likely to choose a tour operator that promotes responsible whale watching practices, with $93.6 \%$ of respondents expressing their likely or very likely intentions to do so (Table 4). Just over two-thirds of survey participants $(68.8 \%)$ said they were likely or very likely to tell someone else about this video, while half (50.1\%) reported being likely or very likely to share the video with friends on social media (e.g. Facebook). Over two-thirds of those who watched the video $(68.8 \%)$ said they were likely or very likely to find out more about good whale watching practices, while $55.2 \%$ said they were likely or very likely to visit the website promoted in the video.

Participants were given 14 different adjectives to describe the video and could choose to agree (Yes), disagree (No) or be undecided. The adjectives are ranked in Table 5 according to the level of agreement from respondents that they described the video. There was very strong agreement $(>80 \%)$ that the video was "believable," "real", "informative" and "engaging". Roughly two-thirds of viewers found the video "motivational," "memorable," "solution-focused," "emotional" and "telling a story." Approximately half considered it "concerning" and "empowering" with somewhat over a third considering it to be "scientific" and "authoritative.". Notably, only 5.7\% considered the video to be "depressing" compared to $84.1 \%$ who did not.

Survey participants were asked to write down what they liked most about the video to see whether they would, of their own volition, identify some of the 
Table 3. Keyframe analysis excerpts of the Good Whale Watching SciCommercial video to illustrate how individual shots support and conform to the SciCommercial format for science storytelling using video.

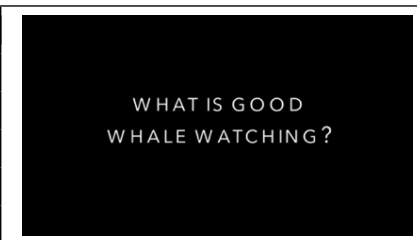

Shot \#2

Length: 3 seconds

Description: dissolve to title slate WHAT IS GOOD WHALE WATCHING? to instantly draw audience attention to the core question of the video. Black coloured sans-serif font. Underwater atmosphere audio with music starting near end of shot. Shot fading to black outro. Purpose: state core question and purpose of video at beginning.

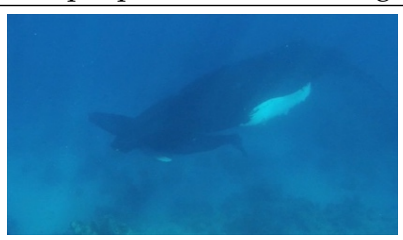

Shot \#3

Length: 15 seconds

Description: fade from black to underwater mid shot of whale calf in very close proximity below whale cow. Purpose: video begins with underwater sound environment to focus on the whale world and perspective from the start as a priority for Good Whale Watching. Long handheld unedited shot used to increase credibility/believability and authenticity of footage. Whale cow and calf portray the sensitive relationship and heightened potential for disturbance. Scientist (initially as voice-only) introduced as first character to focus on the science element yet with unexpected emotional statement to focus on affective elements of whale watching.

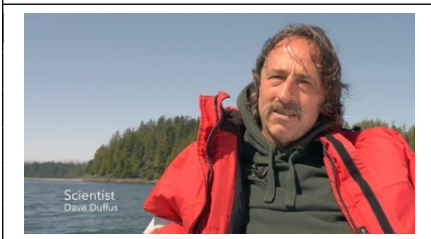

Shot \#4

Length: 2 seconds

Description: straight cut intro to close-up shot of Scientist positioned on right side of screen in marine outdoor setting, natural lighting, blue sky, talking to camera. Purpose: natural setting background as shared environment to remove scientists out of science-lab-setting and into the natural environment.

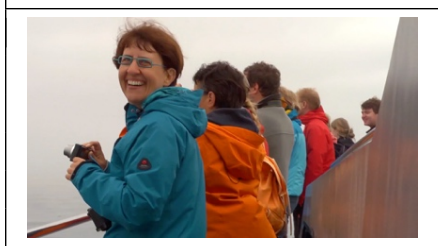

Shot \#6

Length: 3 seconds

Description: straight cut to mid shot of whale watchers in outdoor marine setting, looking and smiling at camera with a number of people in background. Women covers her mouth with delight then turns to another whale watcher. Voice over: "Very, very impressive and beautiful..." Purpose: to show the impact of whale watching on people. Increases credibility of video by capturing authentic human reactions.

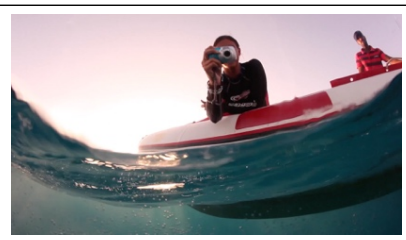

Shot \#19

Length: 1 second

Description: straight cut to low-angle whale point of view shot of person with camera on boat, suggesting the whale's perspective. Purpose: whale's perspective of people looking at it in closeproximity. Forms part of a fast-edited sequence of whale watching shown from the whale's perspective with the voiceover asking audience whether they love and care for whales. Intended to lead to self-reflection instead of simply providing information. 
Table 4. Agreement Rating, Frequencies, Means and Standard Deviation (SD) for After watching the video please rate how likely you are to...

\begin{tabular}{|llllll|}
\hline \multicolumn{5}{|c|}{ Scale of likelihood * } \\
\hline \multicolumn{7}{|c|}{2} & 3 & 4 & 5 \\
\hline Tell someone else about this video \\
$\mathrm{N}$ & 61 & 178 & 219 & 584 & 423 \\
$\%$ & 4.2 & 12.2 & 14.9 & 39.9 & 28.9 \\
Mean & \multicolumn{7}{|c}{} \\
Total (N) & 3.77 & & & \\
\multicolumn{7}{|c}{} \\
Share this video with friends on social media (e.g. Facebook)
\end{tabular}

* = based on a 5-Point Likert Scale of 1= Very Unlikely, 2= Unlikely, 3= Undecided, 4= Likely, $5=$ Very Likely.

SUCCESS communication elements applied as part of the video production process. A total of 1552 people responded to this question by listing one most-liked aspect of the video. The answers fall into seven broad categories (Table 6), with example verbatim quotes from participants.

As society progressively gets more and more of its information and entertainment from online videos, the challenge for science communicators is how to develop stories about science for the online video medium that resonate with the audience, especially when there is so much competition for the audience's attention [Davis and León, 2018]. According to Nisbet and Scheufele [2009, p. 1775], science 
Table 5. Response summary in Frequencies (N) and Percentages (\%) to If you were to describe this video, would you say the video is...

\begin{tabular}{|lrrrrrrrr|}
\hline & \multicolumn{3}{c}{ Yes } & \multicolumn{3}{c}{ No } & \multicolumn{3}{c|}{ Undecided } & \multicolumn{2}{c|}{ Total } \\
& $\mathrm{N}$ & $\%$ & $\mathrm{~N}$ & $\%$ & $\mathrm{~N}$ & $\%$ & $\mathrm{~N}$ & $\%$ \\
\hline Believable & 1330 & 93.9 & 23 & 1.6 & 64 & 4.5 & 1417 & 100 \\
Real & 1292 & 90.8 & 45 & 3.2 & 86 & 6.0 & 1423 & 100 \\
Informative & 1252 & 87.9 & 71 & 5.0 & 101 & 7.1 & 1424 & 100 \\
Engaging & 1152 & 81.4 & 112 & 7.9 & 152 & 10.7 & 1416 & 100 \\
Motivational & 992 & 70.0 & 207 & 14.6 & 219 & 15.4 & 1418 & 100 \\
Memorable & 967 & 68.3 & 225 & 15.9 & 223 & 15.8 & 1415 & 100 \\
Solution-focused & 952 & 67.4 & 219 & 15.5 & 242 & 17.1 & 1413 & 100 \\
Emotional & 914 & 64.5 & 330 & 23.3 & 173 & 12.2 & 1417 & 100 \\
Telling a story & 902 & 63.6 & 338 & 23.8 & 178 & 12.6 & 1418 & 100 \\
Concerning & 752 & 53.3 & 441 & 31.2 & 219 & 15.5 & 1412 & 100 \\
Empowering & 704 & 49.8 & 386 & 27.3 & 324 & 22.9 & 1414 & 100 \\
Scientific & 597 & 42.1 & 517 & 36.5 & 303 & 21.4 & 1417 & 100 \\
Authoritative & 498 & 35.4 & 632 & 44.9 & 278 & 19.7 & 1408 & 100 \\
Depressing & 80 & 5.7 & 1188 & 84.1 & 144 & 10.2 & 1412 & 100 \\
\hline
\end{tabular}

Table 6. Response Frequencies (N) and Percentage (\%) to question What did you like most about the video?

\begin{tabular}{|c|c|c|c|}
\hline Category & $\mathrm{N}$ & $\%$ & Example verbatim quotation \\
\hline $\begin{array}{l}\text { Natural Whale } \\
\text { Images/Sounds }\end{array}$ & 459 & 29.6 & $\begin{array}{l}\text { "Seeing the whales in their natural habitat and hear- } \\
\text { ing their sounds", "The mother and the baby whale to- } \\
\text { gether" }\end{array}$ \\
\hline Simple Message & 430 & 27.7 & $\begin{array}{l}\text { "It was a clear message about respecting them in their } \\
\text { ocean home" }\end{array}$ \\
\hline Video Structure & 175 & 11.3 & $\begin{array}{l}\text { "It was very well-organised, made sense, was easy to } \\
\text { follow" }\end{array}$ \\
\hline Information/Facts & 143 & 9.2 & $\begin{array}{l}\text { "It was respectful and informative" and "had practical } \\
\text { tips", as well as the solution-focused ("liked that the } \\
\text { video gave the viewer information to make better choices } \\
\text { in future") }\end{array}$ \\
\hline $\begin{array}{l}\text { Human-Whale } \\
\text { Interaction }\end{array}$ & 127 & 8.2 & $\begin{array}{l}\text { "Visitors appeared to be at a less intrusive distance and } \\
\text { yet were clearly enjoying the experience" }\end{array}$ \\
\hline $\begin{array}{l}\text { Whale's } \\
\text { Perspective }\end{array}$ & 124 & 7.9 & $\begin{array}{l}\text { "The way it explained whale watching from the whales' } \\
\text { point of view, as many people may not think about that } \\
\text { when they choose to go whale watching" }\end{array}$ \\
\hline $\begin{array}{l}\text { Authentic Human } \\
\text { Reactions }\end{array}$ & 92 & 5.9 & "People's emotional reaction to seeing the whales" \\
\hline Total $(\mathrm{N})$ & 1552 & 100.0 & \\
\hline
\end{tabular}

communication has to investigate "media strategies for "going broad" with science-related content, generating attention and interest among non-elite audiences." The short-form video storytelling format developed here for online videos about science co-opts much of its framework from marketing communication theories and practices, which include drawing on elements of emotion and authenticity. 
Our results point to the potential of this approach: after watching the video, almost all of the respondents (93.6\%) expressed intentions to choose a tour operator who promotes responsible whale watching practices. This highlights the potential of our proposed science communication video format to influence behavioural intentions and, therefore, its potential to impact human behaviour by communicating a simple and concrete message. With regard to this particular aspect of the SUCCESS model in action, we are unable to say what the intentions to choose a responsible whale watching operator would be for respondents who did not see the video. Nevertheless in another part of this study [Finkler, 2018], half of these same respondents formed a control group that were asked before viewing the video if they would choose a whale watching operation based upon how close it got to the whales, while the other half were asked the same question after seeing the video. After seeing the video, survey participants professed to be significantly less likely to choose a whale watch operator that would get them close to the whales compared those in the control group that had not seen the video [Finkler, 2018]. Hence, the video demonstrably altered the viewers' perceptions and, by extension, there is every reason to believe that it influenced the high percentage expressing an intention to utilize responsible whale watching operations in the future.

The vast majority of participants described the Good Whale Watching video as believable, real, informative, engaging, motivational, memorable, solution-focused, emotional and telling a story. It was able to leverage the power of narrative persuasion [Green, 2006; Hoeken and Sinkeldam, 2014] by using the concept of family (a mother and calf) and including information that people can relate to in their own lives (feeding, breeding and sleeping). This use of the mother-child bond increased empathy for the whales through transportation and identification [Bailey, 2012; Green, 2004; Hammond, 2006; Lück, 2015; McKee, 2016; Wiener, 2015; Wright, 2010]. It is an example that emphasises the importance of utilising intrinsic values and universal framing in science storytelling, which allows audience members to see the relevance of stories to themselves [Crompton, 2010].

Our findings indicate that solution-focused emotional storytelling, as used here, can be perceived as real, believable, informative, engaging and - most encouragingly from the point of view of science communication - designed to effect change, motivational and empowering [Voltz and Grobe, 2012]. Our recommended storytelling format is effective for communication because it ultimately focuses on behaviour change by broadening an individuals' thought-action repertoire and promotes the pursuit of a wide range of thoughts, ideas and actions [Garland et al., 2010]. In our example, the science content was successfully packaged in a form that communicates the key science idea while not being heavy-handed with the science. Whereas only $42.1 \%$ of participants described the video as "scientific," the vast majority of them were prepared to accept the science findings that underpinned the video and alter their future whale watching intentions as a consequence. There is a lesson in this, for the communication of science in the online on-demand video medium: that simply being seen as "scientific" is not a formula for success [León and Bourk, 2018]. This is likely to be especially so if trying to: (i) get to a wide audience, and (ii) effect some behavioural change as a consequence of the communication.

Most viewers of our video said they were likely to tell someone else about the video, and share the video on social media: an important component for reaching 
audiences in a marketplace where there is a large amount of competition. This is why the science content when using the SciCommercial format is intentionally packaged non-scientifically: i.e., it is designed to appeal through being emotional and engaging, key elements of user generated content that goes viral [Voltz and Grobe, 2012], thereby increasing the potential virality of its science content. In contrast to user generated content though, our proposed format for short-form science videos utilizes structured narratives and storytelling to inform and elicit intentions for behaviour change in the audience through being also perceived as informative, real, solution-focused and motivational.

To be effective in communicating science in the online video realm, science communicators need to leverage the best of both worlds: combine (i) the viral attraction and social marketing that can be derived from mimicking what makes user generated content successful, with (ii) the motivational storytelling derived from the advertising industry for marketing products. Evidence suggests that viewers watch many short videos on demand and that even if they do stream a longer format video, their attention span makes it unlikely they will continue to watch beyond a few minutes [Davis and León, 2018]. Even the most successful longish-form online video channel, TED talks, limits videos to no more than 18 minutes [Bradbury, 2016]. Respondents liked the short length of the Good Whale Watching SciCommercial video in our study, which is in-line with the suggested potential power of short online narrative videos for engaging audiences [Davis and León, 2018; Roberts, 2005; Wilkinson and Weitkamp, 2016].

Simplifying the message is another key component of the SciCommercial framework for storytelling, which in the whale watching example resonated well with the audience (Table 6). Too often science communicators are wedded to what they perceive as their duty to be true to the science and try to convey all aspects of a science topic, thereby making their stories too complex or burying the main points with qualifiers [Davis, 2010]. By contrast, the lesson from advertisers and marketers is that communication in film or video is most effective when the message is kept simple and unconfused [Shimp and Andrews, 2013; Heath and Heath, 2007], as in our exemplar. Hence, science communicators would be well-advised to spend time to identify and delineate what the simple message is at the core of their reason for communicating with their audience before engaging in any visual storytelling.

\section{Conclusions}

There is no doubt that science communicators need to be where their audience's eyes are, and they are increasingly engaged watching online on-demand videos. While the sheer scale of the competition for the audience's attention in such a medium is daunting, the rise of online video consumption also creates potentially significant opportunities for connecting with audiences through stories about science. The democratization of video-making through the ready availability of inexpensive products for making and editing videos, combined with the easy and cheap channels for distributing videos, also makes this a potentially cost-effective means of science communication. However, we should not kid ourselves that all we have to do is make the videos and put them online to be effective: this democratization of video-making has meant that there is much competition for our audiences' attention. As the results from our video suggest, the adoption of our storytelling framework for short-form science videos using the SUCCESS formula, can not only assist science communicators to get their voices heard, it can be 
effective in changing their attitudes and intentions. As Burns, $\mathrm{O}^{\prime}$ Connor and Stocklmayer [2003, p. 198] emphasize, "science communication is most powerful when it causes participants to reflect on, and form, reform or affirm their attitudes to science and society." Our storytelling format for short-form science videos has the potential to do just that.

\section{Limitations}

The research design had some limitations that should be kept in perspective when considering the results: (i) while the online survey provided a cost- and time-effective means of garnering a large sample size, the online and social media nature of its distribution introduced a self-selection bias, whereby survey completion relied upon the whale-watching interests of people within the sample [Bethlehem, 2010]; (ii) we tested people with a generic interest in whale watching rather than testing actual whale watchers in a whale watching setting; (iii) all respondents viewed the same video; and (iv) the survey measured behavioural intention, which was assumed to be the antecedent of behaviour [Ajzen, 2002], but it was beyond the scope of this research to track actual whale watching behaviour after participants viewed the video.

Acknowledgments The authors would like to thank the Department of Tourism, University of Otago (New Zealand) as well as the Diane Campbell Memorial award for supporting this research. The research was part of a doctoral dissertation funded through a University of Otago Doctoral scholarship.

\section{References}

Ajzen, I. (1991). 'The theory of planned behavior'. Organizational Behavior and Human Decision Processes 50 (2), pp. 179-211. https://doi.org/10.1016/0749-5978(91)90020-T.

- (2002). 'Perceived behavioral control, self-efficacy, locus of control and the theory of planned behavior'. Journal of Applied Social Psychology 32 (4), pp.665-683. https://doi.org/10.1111/j.1559-1816.2002.tb00236.x.

Bagozzi, R. P. (1974). 'Marketing as an organized behavioral system of exchange'. Journal of Marketing 38 (4), p. 77. https ://doi .org/10.2307/1250397.

Bailey, J. L. (2012). 'Whale watching, the Buenos Aires Group and the politics of the International Whaling Commission'. Marine Policy 36 (2), pp. 489-494. https://doi.org/10.1016/j.marpol.2011.09.002.

Barbas, T. A., Paraskevopoulos, S. and Stamou, A. G. (2009). 'The effect of nature documentaries on students' environmental sensitivity: a case study'. Learning, Media and Technology 34 (1), pp. 61-69. https://doi.org/10.1080/17439880902759943.

Beamish, C. (2016). 'Evaluating the effectiveness of advocacy documentary'. Thesis submitted for the degree of Master of Science in Science Communication. Dunedin, New Zealand: University of Otago.

Bejder, L., Samuels, A., Whitehead, H., Gales, N., Mann, J., Connor, R., Heithaus, M., Watson-Capps, J., Flaherty, C. and Krützen, M. (2006). 'Decline in relative abundance of bottlenose dolphins exposed to long-term disturbance'. Conservation Biology 20 (6), pp. 1791-1798. https://doi.org/10.1111/j.1523-1739.2006.00540.x. 
Berger, J. and Milkman, K. L. (2012). 'What makes online content viral?' Journal of Marketing Research 49 (2), pp. 192-205. https: //doi.org/10.1509/jmr.10.0353.

Bethlehem, J. (2010). 'Selection bias in web surveys'. International Statistical Review 78 (2), pp. 161-188. https://doi.org/10.1111/j.1751-5823.2010.00112.x.

Binet, L. and Field, P. (2009). 'Empirical generalizations about advertising campaign success'. Journal of Advertising Research 49 (2), pp. 130-133. https://doi.org/10.2501/s0021849909090163.

Bondebjerg, I. (2014). 'Documentary and cognitive theory: narrative, emotion and memory'. Media and Communication 2 (1), p. 13. https://doi.org/10.17645/mac.v2i1.17.

Bradbury, N. A. (2016). 'Attention span during lectures: 8 seconds, 10 minutes, or more?' Advances in Physiology Education 40 (4), pp. 509-513. https://doi.org/10.1152/advan.00109.2016.

Bryman, A. (2008). Social research methods. 3rd ed. New York, NY, U.S.A.: Oxford University Press.

Bucchi, M. and Trench, B., eds. (2014). Routledge Handbook of Public Communication of Science and Technology. 2nd ed. London, U.K. and New York, U.S.A.: Routledge. https://doi .org/10.4324/9780203483794.

Burns, T. W., O'Connor, D. J. and Stocklmayer, S. M. (2003). 'Science Communication: A Contemporary Definition'. Public Understanding of Science 12 (2), pp. 183-202. https://doi .org/10.1177/09636625030122004.

Cisco (2018). Cisco visual networking index: forecast and trends, 2017-2022. White paper. URL: https://www.cisco.com/c/en/us/solutions/collateral/servic e-provider/visual-networking-index-vni/white-paper-c11-741490.html.

Crompton, T. (2010). Common cause: the case for working with our cultural values.

Davis, L. S. (2010). 'Science communication: a "down under" perspective'. Japanese Journal of Science Communication 7, pp. 65-71.

Davis, L. S. and León, B. (2018). 'New and old narratives: changing narratives of science documentary in the digital environment'. In: Communicating science and technology through online video: researching a new media phenomenon. Ed. by B. León and M. Bourk. Abingdon, U.K.: Routledge, pp. 55-63. https://doi.org/10.4324/9781351054584-5.

de Graaf, A., Hoeken, H., Sanders, J. and Beentjes, J. W. J. (2012). 'Identification as a mechanism of narrative persuasion'. Communication Research 39 (6), pp. 802-823. https://doi.org/10.1177/0093650211408594.

DesAutels, P. (2011). 'UGIS: understanding the nature of user-generated information systems'. Business Horizons 54 (3), pp. 185-192. https://doi.org/10.1016/j.bushor.2010.12.003.

Finkler, W. (2018). 'The science communication of whale watching: a people-focused science communication approach'. Doctor of Philosophy Thesis. Dunedin, New Zealand: University of Otago. URL: http://hdl. handle.net/10523/8012.

Finkler, W. (2014). 'Save the whales part II: a new science advocacy communication framework'. In: Whale-watching: sustainable tourism and ecological management. Ed. by J. Higham, L. Bejder and R. Williams. New York, NY, U.S.A.: Cambridge University Press, pp. 352-364. https://doi.org/10.1017/cbo9781139018166.028. 
Fishbein, M. and Ajzen, I. (1977). Belief, attitude, intention and behavior: an introduction to theory and research.

Foddy, M. and Crundall, I. (1993). 'A field study of social comparison processes in ability evaluation'. British Journal of Social Psychology 32 (4), pp. 287-305. https://doi.org/10.1111/j.2044-8309.1993.tb01002.x.

Garland, E. L., Fredrickson, B., Kring, A. M., Johnson, D. P., Meyer, P. S. and Penn, D. L. (2010). 'Upward spirals of positive emotions counter downward spirals of negativity: insights from the broaden-and-build theory and affective neuroscience on the treatment of emotion dysfunctions and deficits in psychopathology'. Clinical Psychology Review 30 (7), pp. 849-864. https://doi.org/10.1016/j.cpr.2010.03.002.

Green, M. C. (2004). 'Transportation into narrative worlds: the role of prior knowledge and perceived realism'. Discourse Processes 38 (2), pp. 247-266. https://doi.org/10.1207/s15326950dp3802_5.

- (2006). 'Narratives and cancer communication'. Journal of Communication 56 (Supplement 1), S163-S183. https://doi.org/10.1111/j.1460-2466.2006.00288.x.

Green, M. C. and Brock, T. C. (2000). 'The role of transportation in the persuasiveness of public narratives'. Journal of Personality and Social Psychology 79 (5), pp. 701-721. https://doi .org/10.1037/0022-3514.79.5.701.

Gundlach, G. T. (2007). ‘The American Marketing Association's 2004 definition of marketing: perspectives on its implications for scholarship and the role and responsibility of marketing in society'. Journal of Public Policy \& Marketing 26 (2), pp. 243-250. https://doi.org/10.1509/jppm.26.2.243.

Gundlach, G. T. and Wilkie, W. L. (2009). 'The American Marketing Association's new definition of marketing: perspective and commentary on the 2007 revision'. Journal of Public Policy \& Marketing 28 (2), pp. 259-264. https://doi.org/10.1509/jppm.28.2.259.

Hall, C. M. (2014). Tourism and social marketing. Routledge.

Hammond, P. (2006). 'Whale science - and how (not) to use it'. Significance 3 (2), pp. 54-58. https://doi.org/10.1111/j.1740-9713.2006.00160.x.

Hanson, N. R. (1965). Patterns of discovery: an inquiry into the conceptual foundations of science. CUP Archive.

Hassan, S., Nadzim, S. Z. A. and Shiratuddin, N. (2015). 'Strategic use of social media for small business based on the AIDA model'. Procedia - Social and Behavioral Sciences 172, pp. 262-269. https://doi.org/10.1016/j.sbspro.2015.01.363.

Heath, C. and Heath, D. (2007). Made to stick: why some ideas survive and others die. Random House.

Higham, J., Bejder, L. and Williams, R., eds. (2014). Whale-watching: sustainable tourism and ecological management. Cambridge University Press. https://doi.org/10.1017/cbo9781139018166.

Hoeken, H. and Sinkeldam, J. (2014). 'The role of identification and perception of just outcome in evoking emotions in narrative persuasion'. Journal of Communication 64 (5), pp. 935-955. https://doi .org/10.1111/jcom. 12114.

Houston, F. S. and Gassenheimer, J. B. (1987). 'Marketing and exchange'. Journal of Marketing 51 (4), p. 3. https://doi .org/10.2307/1251244. 
Jensen, F. H., Bejder, L., Wahlberg, M., Aguilar de Soto, N., Johnson, M. and Madsen, P. T. (2009). 'Vessel noise effects on delphinid communication'. Marine Ecology Progress Series 395, pp. 161-175. https://doi .org/10.3354/meps08204.

Joffe, H. (2008). 'The power of visual material: persuasion, emotion and identification'. Diogenes 55 (1), pp. 84-93. https://doi.org/10.1177/0392192107087919.

Kaczynski, A. T. (2008). 'A more tenable marketing for leisure services and studies'. Leisure Sciences 30 (3), pp. 253-272. https://doi.org/10.1080/01490400802017464.

Kearney, A. R. (1994). 'Understanding global change: a cognitive perspective on communicating through stories'. Climatic Change 27 (4), pp. 419-441. https://doi.org/10.1007/bf01096270.

Kelsey, E. (2012). 'Why ecologists should look on the bright side'. New Scientist 213 (2846), pp. 24-25. https://doi.org/10.1016/s0262-4079(12)60038-4.

Kietzmann, J. H., Hermkens, K., McCarthy, I. P. and Silvestre, B. S. (2011). 'Social media? Get serious! Understanding the functional building blocks of social media'. Business Horizons 54 (3), pp. 241-251. https://doi.org/10.1016/j.bushor.2011.01.005.

Lee, N. and Kotler, P. (2011). Social marketing: influencing behaviors for good. 4th ed. Thousand Oaks, CA, U.S.A.: SAGE Publications.

Leiserowitz, A. A., Kates, R. W. and Parris, T. M. (2005). 'Do global attitudes and behaviors support sustainable development?' Environment: Science and Policy for Sustainable Development 47 (9), pp. 22-38. https://doi.org/10.3200/envt.47.9.22-38.

León, B. (2007). Science on television: the narrative of scientific documentary. Pantaneto Press.

León, B. and Bourk, M. (2018). Communicating science and technology through online video: researching a new media phenomenon. Routledge.

Lück, M. (2015). 'Education on marine mammal tours - but what do tourists want to learn?' Ocean $\mathcal{E}$ Coastal Management 103, pp. 25-33. https://doi.org/10.1016/j.ocecoaman.2014.11.002.

McIntyre, A. (1984). After virtue Notre Dame. University of Notre Dame Press.

McKee, R. (2016). Dialogue: the art of verbal action for page, stage and screen. U.K.: Hachette.

McKenzie-Mohr, D. (2011). Fostering sustainable behavior: an introduction to community-based social marketing. New society publishers.

Neves, K. (2010). 'Cashing in on cetourism: a critical ecological engagement with dominant E-NGO discourses on whaling, cetacean conservation and whale watching'. Antipode 42 (3), pp. 719-741. https://doi.org/10.1111/j.1467-8330.2010.00770.x.

Nisbet, M. C. and Scheufele, D. A. (2009). 'What's next for science communication? Promising directions and lingering distractions'. American Journal of Botany 96 (10), pp. 1767-1778. https://doi.org/10.3732/ajb. 0900041.

Norman, G. (2010). 'Likert scales, levels of measurement and the "laws" of statistics'. Advances in Health Sciences Education 15 (5), pp. 625-632. https://doi.org/10.1007/s10459-010-9222-y. 
Norman, M. E. (2000). 'Public education through community-based film programs: a report on the environmental film festival in the nation's capital'. The Journal of Environmental Education 31 (2), pp. 28-30. https://doi.org/10.1080/00958960009598636.

O'Connor, S., Campbell, R., Cortez, H. and Knowles, T. (2009). Whale watching worldwide: tourism numbers, expenditures and expanding economic benefits, a special report from the International Fund for Animal Welfare. Yarmouth, MA, U.S.A.

Office of Science and Technology \& Wellcome Trust (2001). 'Science and the public: a review of science communication and public attitudes toward science in Britain'. Public Understanding of Science 10 (3), pp. 315-330. https://doi.org/10.1088/0963-6625/10/3/305.

Olson, R. (2009). Don't be such a scientist: talking substance in an age of style. Washington, DC, U.S.A.: Island Press.

Orams, M. B. (2000). 'Tourists getting close to whales, is it what whale-watching is all about?' Tourism Management 21 (6), pp. 561-569. https://doi.org/10.1016/s0261-5177(00)00006-6.

Parsons, E. C. M. (2012). 'The negative impacts of whale-watching'. Journal of Marine Biology 2012, pp. 1-9. https://doi .org/10.1155/2012/807294.

Pearson, E., Dorrian, J. and Litchfield, C. (2011). 'Harnessing visual media in environmental education: increasing knowledge of orangutan conservation issues and facilitating sustainable behaviour through video presentations'. Environmental Education Research 17 (6), pp. 751-767. https://doi.org/10.1080/13504622.2011.624586.

Peters, H. P. (2014). 'Scientists as public experts: expectations and responsibilities'. In: Routledge handbook of public communication of science and technology. Routledge, pp. 86-98.

Peters, K., Chen, Y., Kaplan, A. M., Ognibeni, B. and Pauwels, K. (2013). 'Social media metrics - a framework and guidelines for managing social media'. Journal of Interactive Marketing 27 (4), pp. 281-298. https://doi.org/10.1016/j.intmar.2013.09.007.

Rieh, S. Y. (2010). 'Credibility and cognitive authority of information'. In: Encyclopedia of library and information sciences. Ed. by M. Bates and M. N. Maack. 3rd ed. New York, NY, U.S.A.: Taylor and Francis Group, LLC, pp. 1337-1344. URL: http: //hdl . handle. net/2027 . 42/106416.

Roberts, K. (2005). Sisomo: the future on screen. Creating emotional connections in the market with sight, sound and motion. PowerHouse Books.

Robson, C. (2011). Real world research: a resource for users of social research methods in applied settings. 3rd ed. Chichester, U.K.: Wiley.

Robson, C. and McCartan, K. (2016). Real world research. Wiley \& Sons.

Roe, A. H. (2014). 'The evolution of animated documentary'. In: New documentary ecologies. Ed. by K. Nash, C. Hight and C. Summerhayes. Springer, pp. 174-191. https://doi.org/10.1057/9781137310491_12.

Saunders, C. D., Brook, A. T. and Myers, O. E. (2006). 'Using psychology to save biodiversity and human well-being'. Conservation Biology 20 (3), pp. 702-705. https://doi.org/10.1111/j.1523-1739.2006.00435.x.

Schwartz, M. W. (2006). 'How conservation scientists can help develop social capital for biodiversity'. Conservation Biology 20 (5), pp. 1550-1552. https://doi.org/10.1111/j.1523-1739.2006.00421.x. 
Shapin, S. (2008). The Scientific Life: A Moral History of a Late-Modern Vocation. Chicago, U.S.A.: Chicago University Press.

Shimp, T. A. and Andrews, J. C. (2013). Advertising, promotion and other aspects of integrated marketing communications. 7th ed. Mason, OH, U.S.A.: Thomson South-Western.

Smith, R. J., Veréssimo, D. and MacMillan, D. C. (2010). 'Marketing and conservation: how to lose friends and influence people'. In: Trade-offs in conservation: deciding what to save. Ed. by N. Leader-Williams, W. M. Adams and R. J. Smith. Wiley-Blackwell, pp. 215-232.

https://doi.org/10.1002/9781444324907.ch12.

Statistic Brain Research Institute (2016). YouTube Company Statistics.

URL: http://www. statisticbrain.com/youtube-statistics (visited on 17th April 2018).

Swaisgood, R. R. and Sheppard, J. K. (2010). 'The culture of conservation biologists: show me the hope!' BioScience 60 (8), pp. 626-630.

https://doi.org/10.1525/bio.2010.60.8.8.

Thomas, J. A. (2014). Meaning in interaction: an introduction to pragmatics. Routledge.

Truong, V. D. and Hall, C. M. (2013). 'Social marketing and tourism: what is the evidence?' Social Marketing Quarterly 19 (2), pp. 110-135.

https://doi.org/10.1177/1524500413484452.

Tyack, P. L. (2008). 'Implications for marine mammals of large-scale changes in the marine acoustic environment'. Journal of Mammalogy 89 (3), pp. 549-558. https://doi.org/10.1644/07-mamm-s-307r.1.

Veríssimo, D. (2013). 'Influencing human behaviour: an underutilised tool for biodiversity management'. Conservation Evidence 10, pp. 29-31.

Voltz, S. and Grobe, F. (2012). The viral video manifesto: why everything you know is wrong and how to do what really works. McGraw Hill Professional.

Vorbau, W. A., Mitchell, A. S. and O'Hara, K. (2007). "'My iPod is my pacifier": an investigation on the everyday practices of mobile video consumption'. In: Eighth IEEE Workshop on Mobile Computing Systems and Applications. IEEE, pp. 29-33. https://doi.org/10.1109/hotmobile.2007.10.

Weinreich, N. K. (2010). Hands-on social marketing: a step-by-step guide to designing change for good. Sage Publications.

Whiteman, D. (2009). 'Documentary film as policy analysis: the impact of yes, in my backyard on activists, agendas and policy'. Mass Communication and Society 12 (4), pp. 457-477. https: //doi.org/10.1080/15205430903237816.

Whiteman, G. (1999). 'Sustainability for the planet: a marketing perspective'. Conservation Ecology 3 (1). https: //doi .org/10.5751/es-00098-030113.

Wiener, C. (2015). 'Flipper fallout'. In: Human-wildlife conflict: complexity in the marine environment. Ed. by F. M. M. Draheim, J. B. McCarthy and E. Parsons. Oxford University Press, pp. 137-158.

https://doi.org/10.1093/acprof: oso/9780199687145.003.0008.

Wijaya, B. S. (2015). 'The development of hierarchy of effects model in advertising'. International Research Journal of Business Studies 5 (1), pp. 73-85. https://doi.org/10.21632/irjbs.5.1.73-85.

Wilkinson, C. and Weitkamp, E. (2016). Creative research communication: Theory and practice. Manchester, U.K.: Manchester University Press. 
Wright, A. J., Soto, N. A., Baldwin, A. L., Bateson, M., Beale, C. M., Clark, C., Deak, T., Edwards, E. F., Fernández, A. and Godinho, A. (2007). 'Do marine mammals experience stress related to anthropogenic noise?' International Journal of Comparative Psychology 20 (2), pp. 274-316.

Wright, A. J., Deak, T. and Parsons, E. (2011). 'Size matters: management of stress responses and chronic stress in beaked whales and other marine mammals may require larger exclusion zones'. Marine Pollution Bulletin 63 (1-4), pp. 5-9. https://doi.org/10.1016/j.marpolbul.2009.11.024.

Wright, A. J., Veríssimo, D., Pilfold, K., Parsons, E. C. M., Ventre, K., Cousins, J., Jefferson, R., Koldewey, H., Llewellyn, F. and McKinley, E. (2015). 'Competitive outreach in the 21st century: why we need conservation marketing'. Ocean $\mathcal{E}$ Coastal Management 115, pp. 41-48. https://doi.org/10.1016/j.ocecoaman.2015.06.029.

Wright, J. H. (2010). 'Use of film for community conservation education in primate habitat countries'. American Journal of Primatology 72 (5), pp. 462-466. https://doi.org/10.1002/ajp. 20749.

Zettl, H. (2013). Sight, sound, motion: applied media aesthetics. Cengage Learning.

Authors

\section{How to cite}

(C) The Author(s). This article is licensed under the terms of the Creative Commons Attribution - NonCommercial - NoDerivativeWorks 4.0 License. ISSN 1824-2049. Published by SISSA Medialab. jcom.sissa.it
Wiebke Finkler is a science communicator, filmmaker and marine biologist based at the University of Otago (New Zealand). Her research interests lie in how science communication videos, when combined with community based social marketing approaches, can be used as a tool for change and social impact of science, sustainable development and conservation. E-mail: wiebke.finkler@otago.ac.nz.

Bienvenido León is an Associate Professor of Science Journalism and Television Production, based at the School of Communication, University of Navarra (Spain). His research interests concentrate on science communication through audio-visual media, especially within the fields of scientific documentaries and science related news. E-mail: bleon@unav.es.

Finkler, W. and León, B. (2019). 'The power of storytelling and video: a visual rhetoric for science communication'. JCOM 18 (05), A02. https://doi.org/10.22323/2.18050202. 